\title{
Resource evaluation of geothermal power plant under the conditions of carboniferous deposits usage in the Dnipro-Donetsk depression
}

\author{
Mykhailo Fyk ${ }^{1 *}$, Volodymyr Biletskyi ${ }^{2}$, and Mokhammed Abbud ${ }^{2}$ \\ ${ }^{1}$ V.N. Karazin Kharkiv National University, School of Geology, Geography, Recreation and Tourism, \\ 4 Svobody Sq., 61022 Kharkiv, Ukraine \\ ${ }^{2}$ National Technical University "Kharkiv Polytechnic Institute", Institute of Chemical Technology \\ and Engineering, 2 Kyrpychova Str., 61002 Kharkiv, Ukraine
}

\begin{abstract}
The objective of the work is to substantiate the actualization of the problem of obtaining geothermal energy from oil and gas wells of oil and gas production facilities in the central-eastern part of the DnieperDonetsk Depression (DDD). The research methodology is based on the collection and statistical processing geophysical data of the DDD oil and gas deposits, the use of balance equations for energy and substance matter. The main result of the work is that the principal technological scheme of the geothermal system has been developed and the geothermal potential of oil and gas wells in the experimental zone has been analyzed. There have been considered the technological and ecological aspects of geothermal heat usage from depleted deposits of the DDD wells, which were disclosed into carboniferous deposits productive horizons.
\end{abstract}

\section{Introduction}

Geothermal power plants (GeoPP) with a binary cycle are based on two closed cycles: one for geothermal liquid or fluid, the second for working fluid or gas with low boiling point. At these power plants, the working fluid heated by geothermal water is converted to steam, then a heat exchanger is used, and finally the steam enters the turbine, ensuring its rotation (Fig. 1). The peculiarity of the binary geothermal power plants work is that a working fluid in them, for example, a two-component water-ammonia mixture or a propane-butane mixture, evaporates at a lower temperature than water. Taking into account that in nature the sources of geothermal water with a temperature below $190^{\circ} \mathrm{C}$ are commonly available at depths up to $3-4 \mathrm{~km}$, then in the future one should expect the predominant construction of geothermal thermal power plants with a binary cycle. For geothermal power plants (GeoPP), even lower wellhead temperatures $\left(40-70^{\circ} \mathrm{C}\right)$ are sufficient. Multistage heat supply systems are built on the principles of cognitive technologies [1] in terms of simultaneous heat utilization and its distribution among consumers, extraction and intensification of hydrocarbon inflows, other extracting fluids [2]. The greatest development of these technologies was in the USA, Germany, Canada. More than $6 \mathrm{mln} \mathrm{m}^{3}$

\footnotetext{
*Corresponding author: mfyk@ukr.net
} 
of geothermal water per year are mined in Dagestan. In the Northern Caucasus, about 500 thousand people use the geothermal water-supply [3]. Capital costs for the GeoPP construction range currently from $\$ 1.500$ to $\$ 2.500$ per kilowatt of installed electric power, compared to a similar economic indicator for nuclear power plants and thermal power plants. The work [2] shows that the use of geothermal heat as a combination of heat and mass transfer processes with the production of hydrocarbons (cognitive-technological approach) is technically and economically profitable. It is shown in [4] that the temperatures of the coolant outlet flow from the Grobla deposit near Krakow reach more than $40{ }^{\circ} \mathrm{C}$ when developing depths of only $900 \mathrm{~m}$. The oil and gas wells survey in the south of Texas [5] have shown the possibility of obtaining up to 3.5 MW of thermal power for wells with a depth of about $3 \mathrm{~km}$, with a circulation velocity of the secondary coolant $3-5 \mathrm{~m} / \mathrm{s}$ and pressures in the wells of $30-40$ bars. The thermal insulation thickness of the well column, as evidenced by the authors of [5], should be not less than 1 inch, which will reduce the loss of the temperature potential up to $3-5^{\circ} \mathrm{C}$. Assessment of the use of abandoned deep hydrocarbon reservoirs and dry wells in the Croatian area of the Pannonian basin (Croatia) as a source of geothermal energy was made in [6]. It is proposed to receive geothermal energy according to the principle of a coaxial heat exchanger. The calculated capacity of the considered GeoPP is $400 \mathrm{~kW}$ (peak is $1.5 \mathrm{MW}$ ) for 20 years of operation, the temperature of the heat transfer fluid reaches a stable state at $50{ }^{\circ} \mathrm{C}$. The model-based analysis [7] of Vilfortune-Trekate, the large European oil field, shows that one well can produce $4 \mathrm{MW}$ of thermal and $400 \mathrm{~kW}$ of electric power at an estimated cost of electricity of 0.05 euro/kWh (Italian consumers). In [8] the heat-flux density in wells of $75-100 \mathrm{~mW} / \mathrm{m}^{2}$ for geological formations of California (Santa Clara, Monterey and Santa Barbara) were investigated.

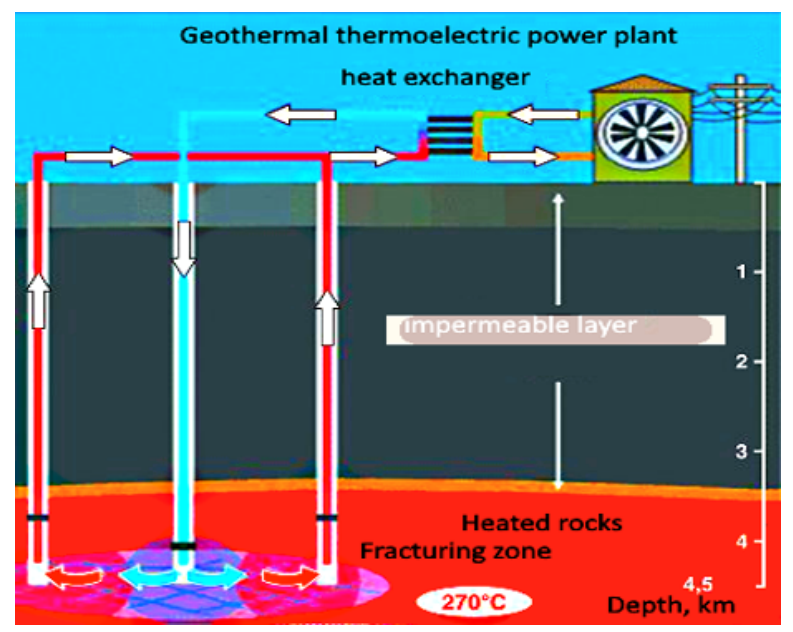

Fig. 1. Binary GeoPP Fractured Reservoirs in Australia.

Work [10] shows the significant potential of depleted and abandoned oil wells in Pakistan from the point of view of geothermal energy of oil and gas reservoirs with significant water-flood operation in the end.

This actualizes the research task of the fluid production thermobaric regimes from the horizons of the DDD carboniferous deposits, the development of multilevel utilization complexes for geothermal heat.

The circulation technology for the development of geothermal deposits with natural reservoirs (Fig. 1) has been successfully applied in France, has industrial distribution in 
Germany, Denmark, Switzerland, the USA, Poland, Russia (Chechnia, Dagestan), Australia, etc. Ukraine also has a binary GeoPP in Autonomous Republic of Crimea. Research GeoPP is also built in Ukraine near the city of Uzhhorod for heat supply of the greenhouse complex and livestock farm; the depth of this system is $2.3 \mathrm{~km}$, the water temperature is $124{ }^{\circ} \mathrm{C}$. In general, there are two main types of geothermal energy sources in the form of dry rocks heat concentrated mainly in the northern and central regions of the country, occurring at depths of up to $5 \mathrm{~km}$ and having relatively low temperatures (up to $100{ }^{\circ} \mathrm{C}$ ), and in the form of thermal waters laying at a depth of up to $3000 \mathrm{~m}$ and heated to $120{ }^{\circ} \mathrm{C}$ that are concentrated in the Autonomous Republic of Crimea, Zakarpattia, Kharkiv and Poltava regions, as well as in the Carpathian region.

\section{Results and discussion}

The research methodology includes the collection and statistical processing of geophysical data of oil and gas wells of the DDD oil and gas deposits. In this case, the balance equations for the energy and substance matter fluxes of the primary and intermediate coolant are used.

The analysis of works $[1-11]$ proves the possibility of using lithologically and tectonically limited reservoirs of the experimental oil and gas deposits for the purposes of space heating and multi-level heat supply. This actualizes the research task of the fluid production thermobaric regimes from the horizons of the DDD carboniferous deposits, the development of multilevel utilization complexes for geothermal heat based on cognitive technologies, and the assessment of the main environmental aspects of the GeoPP implementation.

On the basis of UkrNDIgaz Institute projects for the oil and gas deposits development and the results of works [11 - 13], Table 1 shows the data of 32 oil-gas and gas condensate deposits in the DDD central and eastern area. The calculation of the thermal power is made according to the formulas from $[2,13]$.

It can be seen from Table 1 that most deposits have reservoir temperatures above 50 $60{ }^{\circ} \mathrm{C}$, can be used for local complex heat supply and space heating. In this sample, only three deposits (Leventsivske, Vergunske, Hnidyntsivske - less than 10\%) show a temperature regime of fluids in the carbon less than $50{ }^{\circ} \mathrm{C}$.

By analogy with the operating GeoPP in Germany (see Fig. 2, with a monocycle), a GeoPP scheme has been developed for DDD conditions with three-level heat supply (see Fig. 3, with a full binary cycle).

The schematic diagram (Fig. 3) is completely isolated between the formation circulating coolant (underground circuit) and the water in the heat supply system (the coolant-water circuit in the surface part) due to the heat exchangers of units 4 and 13. The difference between the developed GeoPP scheme and the prototype [12] is in the application of the binary GeoPP principle, as well as in the introduction of the third heat exchanger after leaving the heat pump 13. This allows to work not with three, but with four thermal potentials, indicated in Fig. 2 with different 4 colors.

The underground circuit may contain natural hydrocarbon mixtures. For the deposits considered in Table 1, the extracting hydrocarbon mixtures are oil, gas and gas condensate.

It is submitted the comparative analysis of the Geotech circuitry descriptive variants. The simplest type of GeoPP use: one well is made thermally insulated and lifts hot water or heat coolant (see Fig. 1-3). After passing the heat pump and turbine, cold water is discharged into the same (see Fig. 2) or another (Fig. 3) well at the same depth, the system is hermetically sealed, that is, the pump only overcomes the resistance of the underground filtration and the resistance of the tubing pipes. The second well is made on the contrary as heat-exchanging, so that along the path of discharged water downstream, it begins to be 
heated along the path from the mouth to the productive horizon. With a sufficient flow rate of water or other liquid coolant, a drop of even a few tens of degrees will give economically significant amounts of energy. Instead of water, light oil product can be used.

Table 1. Thermobaric conditions for production of formation fluids from 32 oil and gas fields in the DDD central and eastern area.

\begin{tabular}{|c|l|c|c|c|c|}
\hline № & The oil deposit, (area of DDD) & $\begin{array}{c}\text { Depth } H, \\
\mathrm{~m}\end{array}$ & $\begin{array}{c}\text { Actual } \\
\text { temperature at } \\
\text { depth } H,{ }^{\circ} \mathrm{C}\end{array}$ & $\begin{array}{c}\text { Geothermal } \\
\text { degree at depths } \\
H, \mathrm{~m}^{\circ} \mathrm{C}\end{array}$ & $\begin{array}{c}\text { Heat power } \\
\text { of the well, } \\
\text { MW }\end{array}$ \\
\hline 1 & Leventsivske & 750 & 30 & 33.90 & 0.53 \\
\hline 2 & Verhunske & 1165 & 35 & 43.00 & 0.79 \\
\hline 3 & Zachepylivske & 1350 & 36 & 48.00 & 0.84 \\
\hline 4 & Borivske & 1510 & 55 & 35.00 & 1.84 \\
\hline 5 & Prylutske & 1602 & 63 & 29.10 & 2.26 \\
\hline 6 & Vilkhivske & 1669 & 57 & 33.90 & 1.94 \\
\hline 7 & Hnidyntsivske & 1730 & 45 & 46.60 & 1.31 \\
\hline 8 & Leliakivske & 1850 & 48 & 46.10 & 1.47 \\
\hline 9 & Skhidno-Novoselivske & 1922 & 53 & 42.60 & 1.73 \\
\hline 10 & Novohryhorivske & 2000 & 70 & 32.00 & 2.63 \\
\hline 11 & Kremenivske & 2215 & 64 & 39.40 & 2.31 \\
\hline 12 & Malosorochynske & 2257 & 79 & 31.70 & 3.10 \\
\hline 13 & Krasnopopivske & 2311 & 92 & 27.40 & 3.78 \\
\hline 14 & Shebelynske & 2430 & 64 & 43.30 & 2.31 \\
\hline 15 & Bohdanivske & 2495 & 85 & 31.90 & 3.41 \\
\hline 16 & Pereschepynske & 2640 & 75 & 39.30 & 2.89 \\
\hline 17 & Chornukhinske & 2957 & 84 & 38.80 & 3.36 \\
\hline 18 & Milkivske & 3000 & 89 & 36.90 & 3.62 \\
\hline 19 & Volokhivske & 3060 & 83 & 40.70 & 3.31 \\
\hline 20 & Melykhivske & 3100 & 72 & 45.50 & 2.73 \\
\hline 21 & Velykobubnivske & 3105 & 95 & 35.60 & 3.94 \\
\hline 22 & Solokhivske & 3120 & 88 & 38.90 & 3.57 \\
\hline 23 & Zakhidno-Vedmedivske & 3190 & 75 & 47.50 & 2.89 \\
\hline 24 & Monastyryshchenske & 3355 & 97 & 37.60 & 4.04 \\
\hline 25 & Rybalske & 3384 & 91 & 40.70 & 3.73 \\
\hline 26 & Zakhidno- Khrestyschenske & 3400 & 76 & 49.90 & 2.94 \\
\hline 27 & Verkhnolannivske & 3400 & 74 & 51.40 & 2,84 \\
\hline 28 & Novotroitske & 3400 & 87 & 42.90 & 3.52 \\
\hline 29 & Zakhidno-Sosnivske & 3676 & 78 & 52.40 & 3.05 \\
\hline 30 & Opishnianske & 3695 & 101 & 39.60 & 4,25 \\
\hline 31 & Hlynsko-Rozbyshivske & 3748 & 101 & 40.20 & 4,25 \\
\hline 32 & Mashivske & 4060 & 108 & 40.50 & 4.62 \\
\hline & & & & & \\
\hline
\end{tabular}

Next, we concentrate on the energy calculation of GeoPP geothermal power. Geothermal energy by mass can be obtained from the expression:

$$
W=C(T 1-T 2)=4200(80-30)=210000 \mathrm{~J} / \mathrm{kg},
$$

where $T 1$ is the inlet temperature of the coolant (fluid), $80^{\circ} \mathrm{C}, T 2$ is the outlet temperature of the coolant out of the system, $30^{\circ} \mathrm{C}, \mathrm{C}$ is the thermal power of the fluid.

For the thermal power of the wells (Fig. 3) at water flow rate $Q=20 \mathrm{~kg} / \mathrm{sec}$ we have:

$$
P=Q \cdot W=210000 \cdot 20=4200000 \mathrm{~W} .
$$

Thus, we obtain $\sim 4 \mathrm{MW}$ from two wells with a depth of $3-4 \mathrm{~km}$ (with a difference in temperature on the choke $-50^{\circ} \mathrm{C}$ ). For the above example of implementation in Germany, the temperature at the mouth is $65^{\circ} \mathrm{C}$, and the coolant returns with a temperature of up to $5-$ $15^{\circ} \mathrm{C}$. So, the temperature difference on the choke of the heat pump is more than $50^{\circ} \mathrm{C}$. 


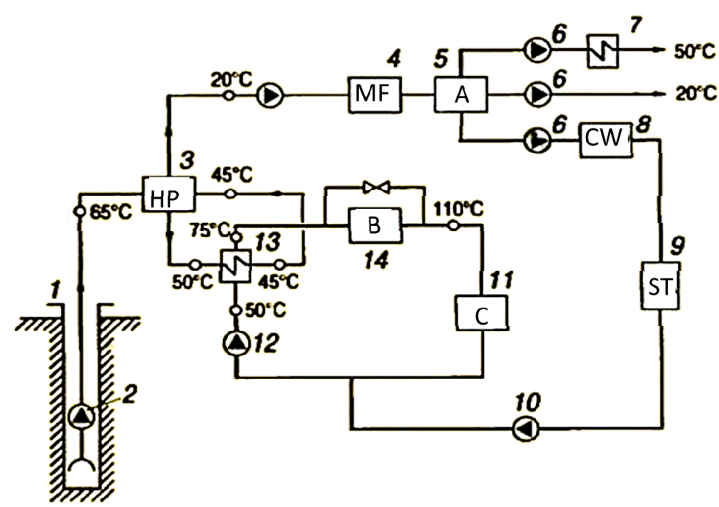

Fig. 2. The technological scheme of GeoPP operating in Germany: 1 - geothermal well with depth of $2350 \mathrm{~m}$ with a temperature of $65^{\circ} \mathrm{C} ; 2$ - submerged-type well pump, which provides geothermal water consumption from 24 to $55 \mathrm{l} / \mathrm{s} ; 3$ - absorption heat pump (HP) with a thermal power of 6.8 MW; 4 - membrane filters that purify geothermal water to the norm of cold water supply (TP); 5 cold water accumulator (A); 6 - cold water pumps; 7 - heat exchanger for water heating for the water park; 8 - chemical water purification of the heat supply system feeding $(\mathrm{CW}) ; 9$ - storage tank for make-up water (B); 10 - feed pump; 11 - consumers of the heat supply system (C); 12 - network pump; 13 - heat pump heat exchanger; 14 - boiler (B).

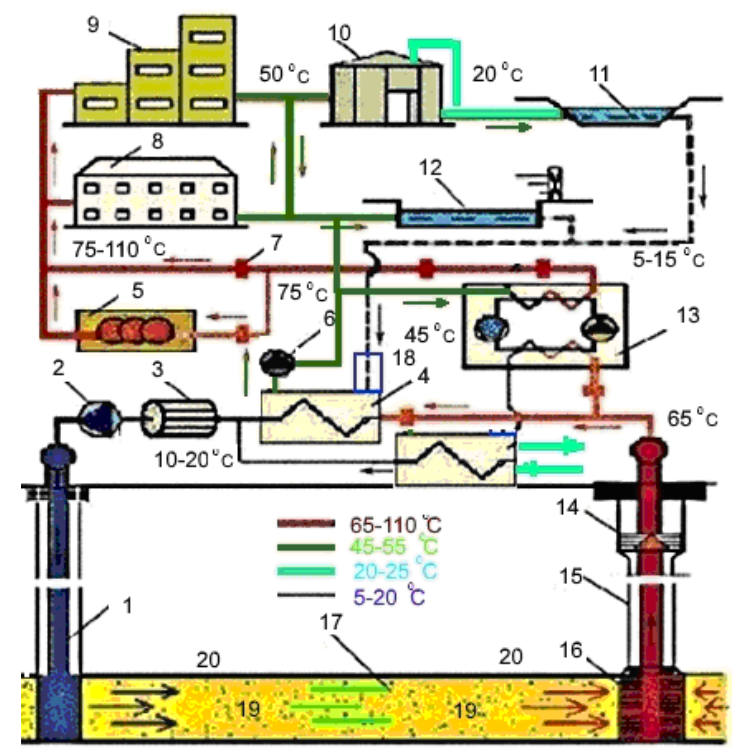

Fig. 3. Schematic diagram of the proposed GeoPP for the development of carboniferous deposits collectors in Ukrainian DDD: 1 - injection well; 2 - surface pump unit; 3 - gas cleaning and coolant preparation system; 4 - heat exchangers; 5 - boiler room for finish heating up (at the outlet to $\left.115^{\circ} \mathrm{C}\right) ; 6$ - network pump; 7 - main heat transport systems; 8 - residential area; 9 - industrial facilities; 10 - greenhouse complex; 11 - fisheries; 12 - balneal and sports complex; 13 - thermal heat pumps (capacity to $6-7 \mathrm{MW}$ ); 14 - submerged-type well pumps; 15 - extracting (water-lifting) heat-insulated well with depth of $750-4000 \mathrm{~m} ; 16$ - bottomhole filter system, submersible well pump (geothermal coolant flow rate from 25 to $501 / \mathrm{s}$ ); 17 - channel of heat exchange between the permeable collector and recycled water; 18 - chemical water purification of the heat supply system feeding; 19 - natural permeable collector; 20 - natural geological impermeable layer. 
Thus, the studies $[1-12]$ and the above-mentioned data prove that two wells disclosed at the depth of carboniferous deposits can confidently provide $0.4-4.5 \mathrm{MW}$ of heat output per local heat supply. The lower and upper limits of the power range comply with experimental studies $[4-9,14]$. The generalization of the data array of the thermal loggings of 130 oil and gas fields wells in the DDD central and eastern area has allowed to synthesize the curve of the trend line $P=f(H)$ - the dependence of the average thermal power $P$ of the well on its depth $H$ (Fig. 4):

$$
P=0.6046 H^{0.5611}
$$

with that the approximation error $R^{2}$, which is greater than 0.8 when using the function (3).

Fig. 4 shows the regression field of the potential thermal power of a well with a flow rate of $25 \mathrm{~kg} / \mathrm{s}$ according to equations $(1-3)$ and data given in Table 1.

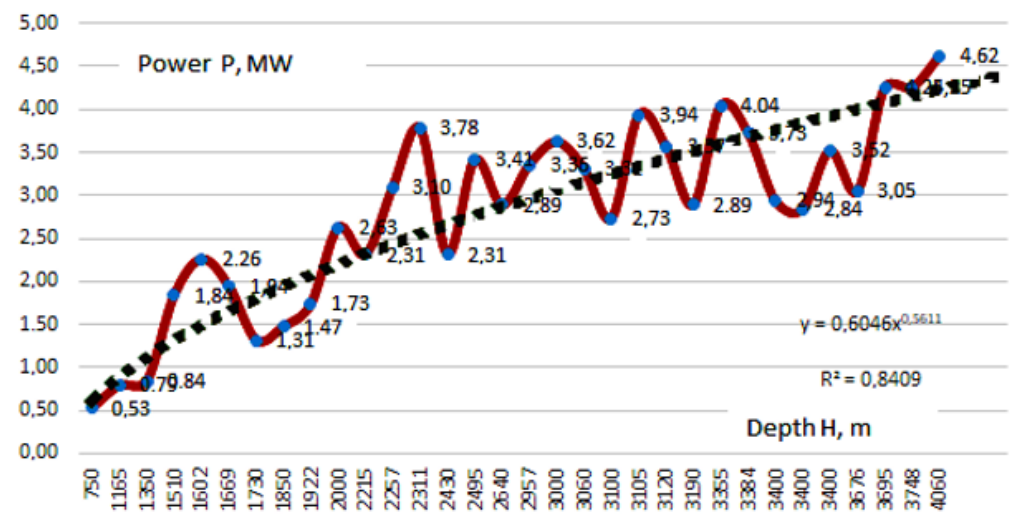

Fig. 4. Dependence of the potential thermal power of the DDD oil and gas wells on the depth.

The calculation of the thermal power (axis of ordinates in Fig. 4, is also shown in the last column of Table 1) is made according to formulas (1 -2) [2] and with account of COP of heat pumps in geothermal systems $(\mathrm{COP}=6-6.2)$, as well as with account of the power efficiency of heat exchangers (49\%) [14]. From Fig. 4 it can be seen that the trend is observed of close to linear increase in the thermal power of the well, and at depths of $2000-3500 \mathrm{~m}$ (where carboniferous deposits are very common in the DDD zone), the theoretically achievable thermal power of a geothermal well is kept at $2.5-4 \mathrm{MW}$. The use of geothermal energy is not associated with the use of significant areas on the Earth's surface and is not accompanied by significant emissions into the atmosphere and waste products. The impact on the environment when using geothermal resources is the least negative among all energy sources. The emissions of carbon dioxide at the modern geothermal power plants are minimal - they are either completely absent or insignificant and amount to about $0.45 \mathrm{~kg}$ per $1 \mathrm{MWh}$ of the volume of electricity produced at the power plant, whereas at a natural gas-fired power plant they amount to $464 \mathrm{~kg}$, on oil - $720 \mathrm{~kg}$, on coal $-819 \mathrm{~kg}$. The process geothermal water or other selected coolant is reliably isolated from groundwater through a pipeline installed into the well. The terrain around the geothermal installation is not spoiled by any mines, nor tunnels, nor piles of waste. Geothermal power plants need very small areas of land, much less than for other types of power plants, and these plants can be located on almost any land, in particular, on agricultural land. For Ukraine with a large area of valuable chernozems, energy technology of this type is indisputably an interesting prospect. 


\section{Conclusions}

The technical and economic analysis carried out by the authors showed that on the basis of the DDD oil and gas wells it is possible to construct geothermal power plants with depths of drilling or disclosing wells up to $3-4.5 \mathrm{~km}$. At such depths, the $90 \%$ thermal potential of geothermal waters in productive oil and gas horizons of carboniferous deposits does not exceed $108^{\circ} \mathrm{C}$. In this case, the replacement of organic fuel and electricity by the heat of geothermal waters and rocks is much more profitable for providing heat and heating (by 3 5 times). Two wells from the depth of carboniferous deposits can provide $0.4-4.5 \mathrm{MW}$ of thermal energy.

The improvement of the technological scheme of the heat supply system from the horizons of DDD oil and gas deposits will lead to an increase by $30-40 \%$ of sampled heat for heating and heat supply purposes. To do this, you need to use a three-stage scheme, which will allow obtaining heat for three different categories of consumers, if it is necessary for the maximum inlet temperature. The calculation carried out by the authors shows that $90 \%$ of the productive horizons of the oil and gas fields of the DDD eastern and central parts are suitable for the construction of GeoPP.

Geothermal heat supply systems are much more environmentally friendly than other heat-generating systems with hydrocarbon fuels. In agriculture, fertile lands will not be disrupted by the secondary use of oil and gas wells.

The authors express their gratitude to the branches of "Ukrhaspromheofizyka" Central Administration and JSC "Ukrhasvydobuvannia" for the provided thermal logging data and professional assistance.

\section{References}

1. Biletskyy, V., Sergeyev, P., \& Krut, O. (2013). Fundamentals of highly loaded coal water slurries. Mining of Mineral Deposits, 105-114. https://doi.org/10.1201/b16354-20

2. Kutia, M., Fyk, M., Kravchenko, O., Palis, S., \& Fyk, I. (2016). Improvement of technologicalmathematical model for the medium-term prediction of the work of a gas condensate field. Eastern-European Journal of Enterprise Technologies, 5(8(83)), 40-48. https://doi.org/10.15587/1729-4061.2016.80073

3. Dobrohotov, V.I. (2003). Ispol'zovaniye geotermal'nykh resursov v energetike Rossii. Teploenergetika, (1), 2-11.

4. Barbacki, A. (2000). The use of abandoned oil and gas wells in poland for recovering geothermal heat. Poland Proceedings World Geothermal Congress (pp. 3361-3365). Kyushu-Tohoku, Japan.

5. Davis, A., \& Michaelides, E. (2009). Geothermal power production from abandoned oil wells. Journal Energy, (34), 866-872.

6. Maceni,' M., Kurevija, T. (2018). Revitalization of abandoned oil and gas wells for a geothermal heat exploitation by means of closed circulation - case study of deep dry well "Pčelić-1". Interpretation, 6(1). https://doi.org/10.1190/INT-2017-0079.1

7. Soldo, E., \& Alimonti, C. (2015). From an Oilfield to a Geothermal One: Use of a Selection Matrix to Choose Between Two Extraction Technologies. Proceedings World Geothermal Congress. Melbourne, Australia, 1-10.

8. Caulk, R., \& Tomac, I. (2017). Reuse of Abandoned Oil and Gas Wells for Geothermal Energy Production. Renewable Energy, (112), 388-397. http://dx.doi.org/10.1016/j.renene.2017.05.042

9. Conser, A. (2013). Double Dipping: Utilizing Oil Wells for Geothermal Energy. Wm. \& Mary Envtl. L. \& Pol'y Rev, 37(3), 813-843. http://scholarship.law.wm.edu/wmelpr/vol37/iss3/7

10. Mehmood, A., Yao, J., Fun, DY., \& Zafar, A. (2017). Geothermal Energy Potential of Pakistan on the Basis of Abandoned Oil and Gas wells. Journal of Petroleum \& Environmental Biotechnology, (7), 332. https://doi.org/10.4172/2157-7463.1000332 
11. Orlov, O., Fyk, I., Bodnarchuk, V., \& Mazur, A. (2015). Bitumonaftohazoheolohichne raionuvannia, naftovi i hazovi rodovyshcha ta pidzemni skhovyshcha hazu v Ukraini. IvanoFrankivsk: Symfoniia forte.

12. Butuzov, V. (2008). Geotermalnoye teplosnabzheniye g. Erdinga v Germanii. Al'ternativnaya energetika i ekologiya, (9), 59-60.

13. Jozsef Nyers (2016). COP and Economic Analysis of the Heat Recovery from Waste Water using Heat Pumps. Acta Polytechnica Hungarica, 13(5), 135-154.

14. Nian, Y-L., \& Cheng, W-L. (2018). Evaluation of geothermal heating from abandoned oil wells. Energy, (142), 592-607. https://doi.org/10.1016/j.energy.2017.10.062 